\title{
WIDE VS. NARROW TAX BASES UNDER OPTIMAL INVESTMENT TIMING
}

\author{
PAOLO M. PANTEGHINI
}

\section{CESIFO WORKING PAPER NO. 1246 \\ CATEGORY 1: PUBlic FinANCE \\ JULY 2004}

Presented at CeSifo Area Conference on Public Sector Economics, MAY 2004 


\title{
WIDE VS. NARROW TAX BASES UNDER OPTIMAL INVESTMENT TIMING
}

\begin{abstract}
This article compares an ACE system with a CBIT system in an open economy. Using a realoption approach we show that, if a firm can decide when to invest, a tradeoff is found. According to traditional wisdom, a high-income firm investing in an ACE system faces a heavier tax burden at each instant. On the other hand, it finds it optimal to invest earlier, thereby enjoying a longer stream of income. If, given the same tax burden, the latter effect is great enough, the firm will prefer the ACE system. In this article we also run a simulation which shows that preference for an ACE system is a realistic result.
\end{abstract}

JEL Code: H25, H32.

Keywords: corporate taxation, open economy, timing and real options.

\author{
Paolo M. Panteghini \\ University of Brescia \\ Department of Economics \\ Via San Faustino 74/B \\ 25122 Brescia \\ Italy \\ panteghi@eco.unibs.it
}

I would like to thank Christian Keuschnigg, Søren Bo Nielsen, Carlo Scarpa, Matthias Wrede, and participants to the 2004 CESifo Area Conference on Public Sector Economics for helpful comments on earlier drafts. 


\section{Introduction}

In the early 90s, two opposing and fairly innovative corporation tax systems were proposed: the Allowance for Corporate Equity (ACE) and the Comprehensive Business Income Tax (CBIT). The implementation of the ACE was advocated by the IFS Capital Taxes Group (1991). Under this system, the tax base is equal to the firm's current earnings, net of the opportunity cost of finance. The CBIT was proposed by the US Treasury Department (1992). It extends the tax base for business, by disallowing interest payments deductibility from the profit tax base. all kinds of capital income are thus taxed at the firm level.

The above systems have different real effects. As argued by Bond (2000), in a closed economy the ACE tax reduces the user cost of capital under equity-financing, while leaving unchanged the tax treatment of debt. This makes the ACE preferable to the CBIT. In a small open economy, instead, the CBIT may be preferred. Since the CBIT system has a wider tax base, it requires a lower tax rate to raise a given amount of revenues. Hence, mobile multinational companies, who usually earn rents, face a less heavy tax burden under such a system.

The above argument against the ACE system disregards two important features of FDIs: their intrinsic riskiness and the ability of firms to choose when to invest. As pointed out by Heckman (2003), the world economy is more variable than it was 30 years ago ${ }^{1}$. Not only business projects are riskier, but also they represent opportunities rather than obligations. Thus, firms behave as if they owned option-rights on business projects. This entails that firms can usually decide when to invest, thereby enjoying a certain degree of flexibility ${ }^{2}$. The value of flexibility can be computed using option pricing techniques ${ }^{3}$.

Using a real-option approach, this article shows that riskiness and busi-

\footnotetext{
${ }^{1}$ The increase in variability is due to increased international mobility of factors and goods; the deregulation of national capital controls and creation of new financial markets; the entry of new countries in international trade, international outsourcing of production on a large scale and, finally, the formidable rise in the use of skill-biased technology.

${ }^{2}$ McDonald and Siegel (1986) show that the opportunity to postpone investment is analogous to a call option.

${ }^{3}$ Graham and Harvey (2001) find that about $25 \%$ of the US companies surveyed always or almost always incorporate real options when evaluating a project. Furhermore, McDonald (2000) argues that even when firms apply standard techniques, it is possible that they adopt ad hoc rules of thumb which proxy for optimal timing behaviour.
} 
ness timing are crucial determinants of FDI strategies in an open economy. According to traditional wisdom, a high-income firm investing in an ACE system faces a heavier tax burden at each instant. On the other hand, the firm may find it optimal to invest earlier under an ACE system, and thus it enjoys a longer stream of income. If, therefore, this latter effect is great enough, the firm will prefer the ACE system even in an open economy.

The paper is structured as follows. Section 2 introduces a continuous-time model and computes the effects of taxation on firms' investment strategies. Section 3 compares the ACE and CBIT system and provides some numerical simulations. Finally, section 4 summarizes the results and discusses some topics for further research.

\section{The model}

In this section we introduce a continuous-time model describing the behavior of a representative firm who decides when to invest. The following hypotheses hold:

1. risk is fully diversifiable and the risk-free interest rate $r$ is given;

2. current income follows a geometric Brownian motion

$$
d Y(t)=\sigma Y(t) d z, \text { with } Y(0)=Y,
$$

where $\sigma$ is the variance parameter and $z$ is a Wiener process ${ }^{4}$;

3. the firm starts to earn the payoff once a non-depreciable sunk cost, say $F$, has been paid ${ }^{5}$;

4. for simplicity the investment project is fully equity financed ${ }^{6}$.

\footnotetext{
${ }^{4}$ More precisely, the dynamics of $Y(t)$ should be written as $d Y(t)=(r-\delta) Y(t) d t+$ $\sigma Y(t) d z$ where $\delta \geq 0$ is the net "dividend" yield, paid out by the firm, and $(r-\delta)$ measures the risk-adjusted rate of return (see McDonald and Siegel, 1985). For simplicity, we thus assume that $r-\delta=0$. As shown in a companion paper (Panteghini, 2002), if $r-\delta \neq 0$, the relevant discount rate would be $\delta$ and the quality of results would be unchanged. For further details see Dixit and Pindyck (1994, Ch. 5 and 6).

${ }^{5}$ As shown in Panteghini (2002), the introduction of depreciation would not affect the qualitative nature of results.

${ }^{6}$ Notice that both the ACE and the CBIT system are expected to be neutral in terms of financial decisions. Thus the qualitive nature of results does not change if we rule out debt-financing. For details on neutrality conditions under ACE taxation, see Bond and Devereux (2003).
} 
Let us next introduce taxation. In line with Boadway and Bruce (1984), the tax base of system $i$ is given by the firm's current income, net of an imputation rate $\rho_{i}$. Given the tax rate $\tau_{i}$, current tax payments are thus equal to

$$
T_{i}(t)=\tau_{i}\left[Y(t)-\rho_{i} F\right] .
$$

The above notation allows a comparison between different tax systems. If we set $\rho_{A C E}=r$ and $\rho_{C B I T}=0$, we obtain an ACE and a CBIT system, respectively. Given (1), the post-tax income can be written as

$$
Y_{i}^{T}(t)=\left(1-\tau_{i}\right) Y(t)+\rho_{i} \tau_{i} F .
$$

Let us next define $V_{i}^{T}(Y)$ as the firm's after-tax project value under system $i$. In this article personal taxation will be disregarded. This can be justified by the fact that in many countries there exist tax-exempt entities (such as pension funds). Hence, investors have the opportunity to choose between taxable FDI projects and a tax-exempt financial investment yielding $r$. For this reason, $r$ will be the relevant discount rate under both the CBIT and the ACE system. Thus the firm's investment decision is one of choosing the optimal investment time, i.e.

$$
\max _{t} E\left\{\left[V_{i}^{T}(Y(t))-F\right] e^{-r t}\right\}
$$

where $E\{$.$\} denotes the expectation operator { }^{7}$. The solution of problem (3), defined as $t_{i}^{*}$, is the optimal time of investment. If, therefore, $t \geq t_{i}^{*}$ immediate investment is undertaken. If, instead, $t<t_{i}^{*}$, the firm will wait until $t=t_{i}^{*}$. It is worth noting that $t_{i}^{*}$ may differ from the laissez-faire optimal timing. In this case, taxation distorts investment timing.

The optimal investment time $t_{i}^{*}$ can be associated with an income level $Y_{i}^{*}$. This entails that whenever the current income reaches $Y_{i}^{*}$, the firm invests. Omitting for simplicity the time variable, we can thus rewrite the firm's problem $\mathrm{as}^{8}$

$$
\ell=\max _{Y_{i}^{*}}\left\{\left(\frac{Y}{Y_{i}^{*}}\right)^{\beta_{1}} \cdot\left[\frac{\left(1-\tau_{i}\right) Y_{i}^{*}}{r}-\left(1-\frac{\rho_{i}}{r} \tau_{i}\right) F\right]\right\} .
$$

The first term of (4), $\left(\frac{Y}{Y_{i}^{*}}\right)^{\beta_{1}}$, is the present value of 1 Euro contingent on future investment and measures the expected discount factor. As can be

\footnotetext{
${ }^{7}$ For further details see Dixit and Pindyck (1994, Ch.6).

${ }^{8}$ For full derivation see the Appendix.
} 
seen, $\left(\frac{Y}{Y_{i}^{*}}\right)^{\beta_{1}}$ depends on both current income, $Y$, and the firm's optimal trigger point $Y_{i}^{*}$. The exponent $\beta_{1}>1$ is a constant which depends on the interest rate and volatility ${ }^{9}$. The second term of (4) measures a perpetual rent, given the starting income $Y_{i}^{*}$.

Solving (4) one obtains the firm's post-tax trigger point

$$
Y_{i}^{*} \equiv\left[\frac{1-\frac{\rho_{i}}{r} \tau_{i}}{1-\tau_{i}}\right] \widetilde{Y},
$$

where $\widetilde{Y} \equiv \frac{\beta_{1}}{\beta_{1}-1} r F>r F$ is the laissez-faire trigger point. Given (5), we can get the economic intuition behind $\beta_{1}$. As explained by Dixit and Pindyck (1994, Ch. 5 and 6 ), the term $\frac{\beta_{1}}{\beta_{1}-1}$ is the 'option value multiple', which accounts for the additional return required to compensate for investment option exercise. Since $\frac{\beta_{1}}{\beta_{1}-1}>1$, inequality $\frac{\tilde{Y}}{F}>r$ holds. According to the static NPV approach, the differential $\left(\frac{\widetilde{Y}}{F}-r\right)$ would be considered as a rent. In an endogenous-time setting, instead, $\left(\frac{\widetilde{Y}}{F}-r\right)$ measures the additional income required to cover the option value. This point, per se, partially explains why firms facing sunk costs may look as high-income companies when they operate in a stochastic context. These firms not only face sunk costs but also lose business flexibility when investment is undertaken ${ }^{10}$. As they give up the opportunity to see how uncertainty is resolved, they must account for an additional opportunity cost, which is equal to the option exercised.

Let us next discuss the effects of taxation. Given (5), we can argue that immediate investment is undertaken if $Y>Y_{i}^{*}$. If, instead, $Y<Y_{i}^{*}$, the firm will wait until $Y$ reaches $Y_{i}^{*}$. Notice that, under an ACE system, we have $\rho_{A C E}=r$ and, hence, $Y_{A C E}^{*}=\widetilde{Y}$. This equality implies that the tax system is neutral, since the firm's investment timing is unaffected by taxation ${ }^{11}$. Under a CBIT system, instead, we have $\rho_{C B I T}=0$. In the absence of any tax benefit related to $F$, therefore, the firm's optimal trigger point is $Y_{C B I T}^{*}=\frac{\widetilde{Y}}{1-\tau_{C B I T}}>\widetilde{Y}$. Such an inequality entails that the CBIT induces an

\footnotetext{
${ }^{9}$ See the Appendix.

${ }^{10}$ As explained by Pindyck (2004), the real-option approach accounts for the basic fact that sunk costs affect investment decision-making when they are not yet sunk.

${ }^{11}$ This neutrality result is equivalent to that obtained in neoclassical model where the firm's user cost is unaffected by taxation.
} 
investment postponement ${ }^{12}$.

Under endogenous timing we face two offsetting effects. On the one hand, the CBIT system is characterised by a wider tax base. Thus it requires a lower tax rate in order to raise a given amount of revenues. At any instant, therefore, high-income firms face a less heavy tax burden under the CBIT system. On the other hand, the inequality $Y_{A C E}^{*}=\widetilde{Y}<Y_{C B I T}^{*}$ implies that companies investing in the ACE country earn profits earlier thereby enjoying a longer stream of profits.

Let us next compute the firm's project value. If $Y>Y_{i}^{*}$ the firm invests immediately and timing does not matter. Thus, the firm's project value is simply $\left[V_{i}^{T}(Y)-F\right]$. If, instead, $Y<Y_{i}^{*}$, the firm waits and timing must be accounted for. Therefore, the firm's value can be written as

$\max _{t} E\left\{\left[V_{i}^{T}(Y)-F\right] e^{-r t}\right\}=\left\{\begin{array}{c}\left(\frac{Y}{Y_{i}^{*}}\right)^{\beta_{1}}\left[\frac{\left(1-\tau_{i}\right) Y_{i}^{*}}{r}-\left(1-\frac{\rho_{i}}{r} \tau_{i}\right) F\right], \text { if } Y<Y_{i}^{*}, \\ {\left[\frac{\left(1-\tau_{i}\right) Y}{r}-\left(1-\frac{\rho_{i}}{r} \tau_{i}\right) F\right], \text { otherwise. }}\end{array}\right.$

Similarly, we can compute the firm's tax burden ${ }^{13}$. If $Y<Y_{i}^{*}$, the firm postpones investment and, therefore, the expected present value of tax payments, defined as $R_{i}(Y)$, depends on both the current level of $Y$ and $Y_{i}^{*}$. If $Y>Y_{i}^{*}$, instead, investment is immediate and only $Y$ matters. As shown in the Appendix we obtain

$$
R_{i}(Y)=\left\{\begin{array}{cc}
\tau_{i}\left[\left(\frac{Y}{Y_{i}^{*}}\right)^{\beta_{1}}\left(\frac{Y_{i}^{*}}{r}-\frac{\rho_{i}}{r} F\right)\right] & \text { if } Y<Y_{i}^{*} \\
\tau_{i}\left(\frac{Y}{r}-\frac{\rho_{i}}{r} F\right) & \text { otherwise. }
\end{array}\right.
$$

Functions (6) and (7) will be used to compare the ACE and the CBIT system.

\section{Tax preferences}

Given the above results, we can now analyse the tax preferences of a representative firm in an open economy.

\footnotetext{
${ }^{12}$ This result is equivalent to that obtained with a neoclassical model, where a CBIT is shown to raise the user cost of capital.

${ }^{13}$ For further details on effective taxation see Panteghini (2003).
} 
Assume that there exist two countries. The first country applies an ACE system (i.e. $\rho_{A C E}=r$ ) with a tax rate $\tau_{A C E}$. The second country implements a CBIT system (i.e. $\rho_{C B I T}=0$ ) with a tax rate $\tau_{C B I T}$. The representative firm must decide in which country to invest.

Given the above assumptions it straightforward to prove the following:

Proposition 1 For any given tax burden, i.e. for

$$
R_{A C E}(Y)=R_{C B I T}(Y) \forall Y>0,
$$

the firm will prefer the ACE country if $Y<Y_{C B I T}^{*}$. Otherwise, the firm will be indifferent.

Proof. See the Appendix.

Proposition 1 shows that a CBIT is never preferred to an ACE system for any given tax burden. As pointed out in the previous section, a firm investing in the ACE country starts to earn profits earlier, thereby enjoying a longer stream of income. Thus the timing effect makes the ACE preferable for $Y<Y_{C B I T}^{*}$.

Proposition 1 is a preliminary result but does not respond to the main argument against the ACE system. If governments set tax rates in line with normal returns, the CBIT might be preferred by firms earning extra-profits. To stress the importance of the timing effect even for high-income firms we define $\widetilde{Y}$ as the normal income and analyse the impact of both systems on high-income firms. Let us then introduce the following:

- Assumption 1: The CBIT country sets $\tau_{C B I T}$, and, in turn, the ACE country sets $\tau_{A C E}$ such that

$$
R_{A C E}(\widetilde{Y})=R_{C B I T}(\widetilde{Y})
$$

According to Assumption 1, the ACE and the CBIT country consider the laissez-faire trigger point $\widetilde{Y}$ as the normal return and set tax rates in order to collect the same tax revenues. Given Proposition 1, the 'normal' firm chooses the ACE country and invests immediately. However, the focus of our analysis is not on normal returns but rather on FDI decisions yielding an above-normal profitability. For this reason, we will analyse the investment decisions by firms whose current income is $Y>Y_{C B I T}^{*}$. According to traditional wisdom, these firms would choose a CBIT country. As will be shown the converse may be true. In fact, it is straightforward to prove that: 
Proposition 2 Given Assumption 1, a high-income firm with $Y>Y_{C B I T}^{*}$ will prefer the ACE system if

i) either $\tau_{C B I T}$ is low enough and $Y \in\left(Y_{C B I T}^{*}, \widehat{Y}\right)$, with $\widehat{Y} \equiv \frac{\beta_{1}\left(1-\tau_{C B I T}\right)^{\beta_{1}-1}}{\beta_{1}\left(1-\tau_{C B I T}\right)^{\beta_{1}-1}-1} r F$,

ii) or $\tau_{C B I T}$ is high enough.

Proof. See the Appendix.

Proposition 2 highlights the importance of timing to determine tax preferences even for high-income firms. In line with the traditional results it is shown that the CBIT system may be preferred if both $\tau_{C B I T}$ is low enough and the firm's income is high enough. However, we prove that even if there exists a threshold value $\widehat{Y}$ above which the CBIT is preferred (point i) of Proposition 2), this is much higher than usually thought.

To give a feeling of the differential $(\widehat{Y}-\widetilde{Y})$, we run a simulation and compare the results with Fama and French's (1997) estimates of 48 US industries, over the 1963-1994 period (see See Table 7, pp. 172-173). In line with empirical evidence ${ }^{14}$, we set $r=0.04$ and $\sigma=0.20^{15}$. Given these parameters, it is straightforward to show that if $\tau_{C B I T}<50 \%$, then point i) of Proposition 2 will be applied.

Let us next analyse two scenarios. In the first one, we set $\tau_{C B I T}=31 \%$, which is the rate suggested in 1992 by the US Treasury ${ }^{16}$. In this case, the $\mathrm{ACE}$ tax rate ensuring equality (9) will then be $\tau_{A C E}^{*}=42.78 \%$. In the second scenario, we account for some tax competition pressure, registered over the last decade, and set $\tau_{C B I T}=25 \%$. In this case, the ACE tax rate yielding (9) will be $\tau_{A C E}^{*}=37.50 \%$. We can thus compute the firm's returns exceeding the risk-free interest rate.

As shown in Table 1, if the net return is $4 \%$ then investment is immediately undertaken under the ACE system. If the CBIT system is considered, instead, threshold returns are higher (i.e. $7.59 \%$ and $6.67 \%$, respectively). The last row of Table 1 finally reports the threshold values above which the

\footnotetext{
${ }^{14}$ See e.g. Jorion and Goetzman (1999) and Dimson et al. (2002).

${ }^{15}$ Notice that the parameter values used in our simulation coincide with the benchmark assumptions in Dixit and Pindyck (1994, p. 153).

${ }^{16}$ See the US Department of the Treasury (1992).
} 
CBIT country is preferred. As can be seen, they are fairly high.

$$
\begin{aligned}
& \text { Table } 1 \text { : A numerical simulation (values in \%) } \\
& \tau_{C B I T}=31 \% \quad \tau_{C B I T}=25 \% \\
& \begin{array}{ccc}
\tau_{A C E}^{*} & 42.78 & 37.50 \\
\widetilde{\widetilde{Y}} F-r & 4.00 & 4.00 \\
\frac{Y_{C B I T}^{*}-r}{F} & 7.59 & 6.67 \\
\frac{F}{F}-r & 10.52 & 8.00
\end{array}
\end{aligned}
$$

Let us then compare the above results with Fama and French's estimates. Under a three-factor model, if $\tau_{C B I T}=31 \%$, only real estates among the 48 industries shows a cost of capital, which is slightly higher than the threshold return $\left(\frac{\widehat{Y}}{F}-r\right)$ (i.e. $11.16 \%$ versus $10.52 \%$ ). When we set $\tau_{C B I T}=25 \%$, 12 industries show an average return which overcomes $\left(\frac{\widehat{Y}}{F}-r\right)$. If, finally, a CAPM is applied, all industries' returns are far below $\left(\frac{\widehat{Y}}{F}-r\right)$, irrespective of the value of $\tau_{C B I T}$ applied. We can thus conclude that, in most cases, an ACE system would be preferred.

\section{Conclusion}

In this paper we have compared an ACE and a CBIT system in an open economy. As we know, the CBIT may require a lower statutory tax rate to gather the same amount of tax revenues. According to traditional wisdom, therefore, mobile multinational companies, who usually earn rents, would prefer the CBIT system.

As we have pointed out, the above argument disregards two important features of FDIs: their intrinsic riskiness and the ability of firms to choose when to invest. When introducing both assumptions, we have two offsetting effects. On the one hand, a firm investing in an ACE system faces a heavier tax burden at each instant. On the other hand, the firm starts to earn profits earlier, thereby enjoying a longer stream of profits. If the latter effect is great enough, the ACE system is preferred even in an open economy.

This article should be considered as the starting point for future research. In particular, a natural extension of the model would be the introduction of tax competition between the ACE and the CBIT country. Another interest- 
ing topic would be the analysis of how tax avoidance strategies differ among the two systems.

\section{Appendix}

\subsection{The computation of the objective function (4)}

Let us write the Bellman function of $V_{i}^{T}(Y)$ as

$$
V_{i}^{T}(Y)=Y_{i}^{T} d t+e^{-r d t} E\left[V_{i}^{T}(Y+d Y)\right] .
$$

Assume that the boundary condition $V(0)=0$ holds. This implies that if $Y$ goes to zero, it will stay at zero ${ }^{17}$. Moreover, assume that if $Y$ goes to infinity, no financial bubbles exist. Given the above boundary conditions, we obtain the solution of (10)

$$
V_{i}^{T}(Y)=\frac{\left(1-\tau_{i}\right) Y}{r}+\frac{\rho_{i}}{r} \tau_{i} F
$$

Notice that a Brownian motion satisfies the Markov property. Namely, the probability of distribution for all future values of $Y$ depends only on its current value. Applying this Property and using the trigger point $Y_{i}^{*}$, one can rewrite (3) as

$$
\max _{t} E\left\{\left[V_{i}^{T}(Y)-F\right] e^{-r t}\right\}=\max _{t} E\left[e^{-r t}\right]\left[V_{i}^{T}\left(Y_{i}^{*}\right)-F\right] .
$$

Following Harrison (1985) it is easy to ascertain that

$$
\max _{t} E\left[e^{-r t}\right]=E\left[e^{-r t_{i}^{*}}\right]=\left(\frac{Y}{Y_{i}^{*}}\right)^{\beta_{1}} \text { for } Y<Y_{i}^{*},
$$

where $\beta_{1}>1$ is the positive root of the characteristic equation $\Psi(\beta) \equiv$ $\frac{\sigma^{2}}{2} \beta(\beta-1)-r=0$. Using (11), (12) and (13) one obtains (4).

\subsection{The computation of (7)}

Given (1), the present value of tax payments is

$$
R_{i}=E\left\{e^{-r t_{i}^{*}}\left[\int_{t_{i}^{*}}^{\infty} T_{i}(s) e^{-r s} d s\right]\right\} .
$$

\footnotetext{
${ }^{17}$ For further details on this absorbing barrier see Harrison (1985, Ch. 3).
} 
Easy computations show that, if $t<t_{i}^{*}$, (14) can be written as

$$
R_{i}=E\left[e^{-r t_{i}^{*}}\right]\left[\tau_{i}\left(\frac{Y-\rho_{i} F}{r}\right)\right] .
$$

If, instead, $t>t_{i}^{*}$, the present value of tax payments is simply

$$
R_{i}=\tau_{i}\left(\frac{Y-\rho_{i} F}{r}\right)
$$

Using (13), (15) and (16) we thus obtain (7).

\subsection{Proof of Proposition 1}

Given inequality $Y_{A C E}^{*}=\widetilde{Y}<Y_{C B I T}^{*}$, we have three cases:

1. $Y<Y_{A C E}^{*}<Y_{C B I T}^{*}$,

2. $Y_{A C E}^{*}<Y<Y_{C B I T}^{*}$,

3. $Y_{A C E}^{*}<Y_{C B I T}^{*}<Y$.

We will analyse the above cases under condition (8).

Case 1: If $Y<Y_{A C E}^{*}$, under both regimes the firm will postpone investment. In this case, the ACE system is preferred to the CBIT one if the ACE pre-tax net present value is greater than the CBIT one. Given (6), (7) and (8), one can show that the ACE system is preferable if

$$
\left(\frac{Y}{Y_{A C E}^{*}}\right)^{\beta_{1}}\left(\frac{Y_{A C E}^{*}}{r}-F\right)>\left(\frac{Y}{Y_{C B I T}^{*}}\right)^{\beta_{1}}\left(\frac{Y_{C B I T}^{*}}{r}-F\right) .
$$

Inequality (17) can be rewritten as

$$
g\left(\tau_{C B I T} ; \beta_{1}\right)>1
$$

where $g\left(\tau_{C B I T} ; \beta_{1}\right) \equiv\left(1-\tau_{C B I T}\right)^{-\left(\beta_{1}-1\right)}\left[\frac{1}{\tau_{C B I T}\left(\beta_{1}-1\right)+1}\right]$. Notice that $g\left(0 ; \beta_{1}\right)=$ 1 and that $\frac{\partial g\left(\tau_{C B I T} ; \beta_{1}\right)}{\partial \tau_{C B I T}}>0$. This is sufficient to prove that $g\left(\tau_{C B I T} ; \beta_{1}\right)>1$ $\forall \tau_{C B I T}>0$. Accordingly, (17) always holds $\forall \tau_{C B I T}>0$. 
Case 2: If $Y \in\left(Y_{A C E}^{*}, Y_{C B I T}^{*}\right)$, investment is immediately undertaken in the ACE country, while it is postponed in the CBIT one. Given (8), the ACE country is preferred to the CBIT one if

$$
\left(\frac{Y}{r}-F\right)>\left(\frac{Y}{Y_{C B I T}^{*}}\right)^{\beta_{1}}\left(\frac{Y_{C B I T}^{*}}{r}-F\right) .
$$

Inequality (18) can be rewritten as $f(Y)>f\left(Y_{C B I T}^{*}\right)$, where $f(Y) \equiv$ $\frac{Y-r F}{Y^{\beta} 1}$. It is straightforward to show that $\frac{\partial f(Y)}{\partial Y}=\frac{\left(\beta_{1}-1\right)(\tilde{Y}-Y)}{Y^{\beta} 1^{+1}}$. Since $Y \in$ $\left(Y_{A C E}^{*}, Y_{C B I T}^{*}\right)$, we have $\frac{\partial f(Y)}{\partial Y}<0$. This is sufficient to state that inequality $f(Y)>f\left(Y_{C B I T}^{*}\right)$ holds for $Y \in\left(Y_{A C E}^{*}, Y_{C B I T}^{*}\right)$. Hence, (18) always holds.

Case 3: If, finally, $Y>Y_{C B I T}^{*}$, the firm will immediately invest irrespective of the tax system. Given condition (8), the pre-tax present value will be $\left(\frac{Y}{r}-F\right)$, under both systems. This leads to indifference.

Proposition 1 is thus proven.

\subsection{Proof of Proposition 2}

According to Assumption 1, the ACE country sets $\tau_{A C E}$ so as to obtain (9). Substituting (7) into (9) yields

$$
\tau_{A C E}\left(\frac{Y_{A C E}^{*}}{r}-F\right)=\left(\frac{Y_{A C E}^{*}}{Y_{C B I T}^{*}}\right)^{\beta_{1}} \tau_{C B I T}\left(\frac{Y_{C B I T}^{*}}{r}\right) .
$$

Using (5), equation (19) reduces to

$$
\tau_{A C E}=\beta_{1} \tau_{C B I T}\left(1-\tau_{C B I T}\right)^{\beta_{1}-1} .
$$

Given (20), therefore, we can show that $\tau_{A C E}>\tau_{C B I T}$ if $\beta_{1}\left(1-\tau_{C B I T}\right)^{\beta_{1}-1}>$ 1 , and vice versa.

Let us next focus on the high-income firm (with $Y>Y_{C B I T}^{*}$ ). Define $N B$ as the net benefit arising from investing in the ACE country. $N B$ is given by the difference between the post-tax NPV under the ACE regime and that obtained under the CBIT one. Notice that, given inequality $Y>Y_{C B I T}^{*}$, the firm will immediately invest irrespective of the tax system. Thus, $N B$ will be

$$
N B=\frac{\left(1-\tau_{A C E}\right)(Y-r F)}{r}-\frac{\left(1-\tau_{C B I T}\right) Y-r F}{r} \text { for } Y>Y_{C B I T}^{*} .
$$


If $\tau_{A C E}>\tau_{C B I T}$ (i.e. $\left.\beta_{1}\left(1-\tau_{C B I T}\right)^{\beta_{1}-1}>1\right)$, the level of current income is crucial for the firm's preferences. Substituting (20) into (21) yields

$$
N B=\frac{\tau_{C B I T}\left[\beta_{1}\left(1-\tau_{C B I T}\right)^{\beta_{1}-1}-1\right]}{r}(\widehat{Y}-Y),
$$

with $\widehat{Y} \equiv \frac{\beta_{1}\left(1-\tau_{C B I T}\right)^{\beta_{1}-1}}{\beta_{1}\left(1-\tau_{C B I T}\right)^{\beta_{1}-1}-1} r F>Y_{C B I T}^{*}$. This entails that $N B$ is positive if $Y<\widehat{Y}$. This proves point i) of Proposition 2 .

Let us next turn to point ii). If $\tau_{A C E}<\tau_{C B I T}$ (i.e. $\beta_{1}\left(1-\tau_{C B I T}\right)^{\beta_{1}-1}<$ 1 ), it is straightforward to show that $N B=\frac{\left(\tau_{C B I T}-\tau_{A C E}\right) Y+\tau_{A C E} r F}{r}>0$ $\forall Y>0$. This completes Proposition 2 . 


\section{References}

[1] Boadway R. and N. Bruce (1984), A General Proposition on the Design of a Neutral Business Tax, Journal of Public Economics, 24, pp. 231-239.

[2] Bond S.R. (2000), Levelling Up or Levelling Down? Some Reflections in the ACE and CBIT Proposals, and the Future of the Corporate Tax Base, in S. Cnossen (ed.), Taxing Capital Income in the European Union - Issues and Options for Reform, Oxford University Press, Oxford.

[3] Bond S.R. and M.P. Devereux (2003), Generalised R-based and S-based Taxes under Uncertainty, Journal of Public Economics, 87, pp. 12911311.

[4] Dimson E., P. Marsh and M. Staunton (2002), Triumph of the Optimists, Princeton University Press.

[5] Dixit A. and R.S. Pindyck (1994), Investment under Uncertainty, Princeton University Press.

[6] Fama E.F. and K.R. French (1997), Industry Costs of Equity, Journal of Financial Economics, 43, pp. 153-193.

[7] Graham J.R. and C.R. Harvey (2001), The Theory and Practice of Corporate Finance: Evidence from the Field, Journal of Financial Economics, 60, pp.187-243.

[8] Harrison J.M. (1985), Brownian Motion and Stochastic Flow Systems, John Wiley \& Sons, New York.

[9] Heckman J. (2003), The Labour Market and the Job Miracle, CESifo Forum, 4, No. 2., pp.29-32.

[10] IFS Capital Taxes Group (1991), Equity for Companies: a Corporation Tax for the 1990s, A Report of the IFS Capital Taxes Group chaired by M. Gammie, The Institute for Fiscal Studies, Commentary 26, London.

[11] Jorion P. and W.N. Goetzman (1999), Global Stock Markets in the Twentieth Century, Journal of Finance, 54, pp. 953-80. 
[12] McDonald R. (2000), Real Options and Rules of Thumb in Capital Budgeting, in M.J. Brennan and L. Trigeorgis (editors), Project Flexibility, Agency, and Competition, New Developments in the Theory and Application of Real Options, Oxford University Press.

[13] McDonald R. and D. Siegel (1985), Investment and the Valuation of Firms When There is an Option to Shut Down, International Economic Review, 26, pp. 331-349.

[14] McDonald R. and D. Siegel (1986), The Value of Waiting to Invest, Quarterly Journal of Economics, 101, pp. 707-728.

[15] Panteghini P.M. (2002), Endogenous Timing and the Taxation of Discrete Investment Choices, CESifo Working Paper Series no. 723.

[16] Panteghini P.M. (2003), A Dynamic Measure of the Effective Tax Rate, Economics Bulletin, Vol. 8 No. 15, pp.1-7.

[17] Pindyck R.S. (2004), Mandatory Unbundling and Irreversible Investment in Telecom Networks, NBER Working Paper Series no. 10287.

[18] U.S. Department of the Treasury (1992), Integration of the Individual and Corporate Tax System: Taxing Business Income Once, Washington, D.C. 


\section{CESifo Working Paper Series}

(for full list see www.cesifo.de)

1181 Michael Hoel, Tor Iversen, Tore Nilssen, and Jon Vislie, Genetic Testing and Repulsion from Chance, April 2004

1182 Paul De Grauwe and Gunther Schnabl, Exchange Rate Regimes and Macroeconomic Stability in Central and Eastern Europe, April 2004

1183 Arjan M. Lejour and Ruud A. de Mooij, Turkish Delight - Does Turkey's accession to the EU bring economic benefits?, May 2004

1184 Anzelika Zaiceva, Implications of EU Accession for International Migration: An Assessment of Potential Migration Pressure, May 2004

1185 Udo Kreickemeier, Fair Wages and Human Capital Accumulation in a Global Economy, May 2004

1186 Jean-Pierre Ponssard, Rent Dissipation in Repeated Entry Games: Some New Results, May 2004

1187 Pablo Arocena, Privatisation Policy in Spain: Stuck Between Liberalisation and the Protection of Nationals' Interests, May 2004

1188 Günter Knieps, Privatisation of Network Industries in Germany: A Disaggregated Approach, May 2004

1189 Robert J. Gary-Bobo and Alain Trannoy, Efficient Tuition Fees, Examinations, and Subsidies, May 2004

1190 Saku Aura and Gregory D. Hess, What's in a Name?, May 2004

1191 Sjur Didrik Flåm and Yuri Ermoliev, Investment Uncertainty, and Production Games, May 2004

1192 Yin-Wong Cheung and Jude Yuen, The Suitability of a Greater China Currency Union, May 2004

1193 Inés Macho-Stadler and David Pérez-Castrillo, Optimal Enforcement Policy and Firms' Emissions and Compliance with Environmental Taxes, May 2004

1194 Paul De Grauwe and Marianna Grimaldi, Bubbles and Crashes in a Behavioural Finance Model, May 2004

1195 Michel Berne and Gérard Pogorel, Privatization Experiences in France, May 2004 
1196 Andrea Galeotti and José Luis Moraga-González, A Model of Strategic Targeted Advertising, May 2004

1197 Hans Gersbach and Hans Haller, When Inefficiency Begets Efficiency, May 2004

1198 Saku Aura, Estate and Capital Gains Taxation: Efficiency and Political Economy Consideration, May 2004

1199 Sandra Waller and Jakob de Haan, Credibility and Transparency of Central Banks: New Results Based on Ifo's World Economicy Survey, May 2004

1200 Henk C. Kranendonk, Jan Bonenkamp, and Johan P. Verbruggen, A Leading Indicator for the Dutch Economy - Methodological and Empirical Revision of the CPB System, May 2004

1201 Michael Ehrmann, Firm Size and Monetary Policy Transmission - Evidence from German Business Survey Data, May 2004

1202 Thomas A. Knetsch, Evaluating the German Inventory Cycle - Using Data from the Ifo Business Survey, May 2004

1203 Stefan Mittnik and Peter Zadrozny, Forecasting Quarterly German GDP at Monthly Intervals Using Monthly IFO Business Conditions Data, May 2004

1204 Elmer Sterken, The Role of the IFO Business Climate Indicator and Asset Prices in German Monetary Policy, May 2004

1205 Jan Jacobs and Jan-Egbert Sturm, Do Ifo Indicators Help Explain Revisions in German Industrial Production?, May 2004

1206 Ulrich Woitek, Real Wages and Business Cycle Asymmetries, May 2004

1207 Burkhard Heer and Alfred Maußner, Computation of Business Cycle Models: A Comparison of Numerical Methods, June 2004

1208 Costas Hadjiyiannis, Panos Hatzipanayotou, and Michael S. Michael, Pollution and Capital Tax Competition within a Regional Block, June 2004

1209 Stephan Klasen and Thorsten Nestmann, Population, Population Density, and Technological Change, June 2004

1210 Wolfgang Ochel, Welfare Time Limits in the United States - Experiences with a New Welfare-to-Work Approach, June 2004

1211 Luis H. R. Alvarez and Erkki Koskela, Taxation and Rotation Age under Stochastic Forest Stand Value, June 2004

1212 Bernard M. S. van Praag, The Connexion Between Old and New Approaches to Financial Satisfaction, June 2004 
1213 Hendrik Hakenes and Martin Peitz, Selling Reputation When Going out of Business, June 2004

1214 Heikki Oksanen, Public Pensions in the National Accounts and Public Finance Targets, June 2004

1215 Ernst Fehr, Alexander Klein, and Klaus M. Schmidt, Contracts, Fairness, and Incentives, June 2004

1216 Amihai Glazer, Vesa Kanniainen, and Panu Poutvaara, Initial Luck, Status-Seeking and Snowballs Lead to Corporate Success and Failure, June 2004

1217 Bum J. Kim and Harris Schlesinger, Adverse Selection in an Insurance Market with Government-Guaranteed Subsistence Levels, June 2004

1218 Armin Falk, Charitable Giving as a Gift Exchange - Evidence from a Field Experiment, June 2004

1219 Rainer Niemann, Asymmetric Taxation and Cross-Border Investment Decisions, June 2004

1220 Christian Holzner, Volker Meier, and Martin Werding, Time Limits on Welfare Use under Involuntary Unemployment, June 2004

1221 Michiel Evers, Ruud A. de Mooij, and Herman R. J. Vollebergh, Tax Competition under Minimum Rates: The Case of European Diesel Excises, June 2004

1222 S. Brock Blomberg and Gregory D. Hess, How Much Does Violence Tax Trade?, June 2004

1223 Josse Delfgaauw and Robert Dur, Incentives and Workers' Motivation in the Public Sector, June 2004

1224 Paul De Grauwe and Cláudia Costa Storti, The Effects of Monetary Policy: A MetaAnalysis, June 2004

1225 Volker Grossmann, How to Promote R\&D-based Growth? Public Education Expenditure on Scientists and Engineers versus R\&D Subsidies, June 2004

1226 Bart Cockx and Jean Ries, The Exhaustion of Unemployment Benefits in Belgium. Does it Enhance the Probability of Employment?, June 2004

1227 Bertil Holmlund, Sickness Absence and Search Unemployment, June 2004

1228 Klaas J. Beniers and Robert Dur, Politicians' Motivation, Political Culture, and Electoral Competition, June 2004

1229 M. Hashem Pesaran, General Diagnostic Tests for Cross Section Dependence in Panels, July 2004 
1230 Wladimir Raymond, Pierre Mohnen, Franz Palm, and Sybrand Schim van der Loeff, An Empirically-Based Taxonomy of Dutch Manufacturing: Innovation Policy Implications, July 2004

1231 Stefan Homburg, A New Approach to Optimal Commodity Taxation, July 2004

1232 Lorenzo Cappellari and Stephen P. Jenkins, Modelling Low Pay Transition Probabilities, Accounting for Panel Attrition, Non-Response, and Initial Conditions, July 2004

1233 Cheng Hsiao and M. Hashem Pesaran, Random Coefficient Panel Data Models, July 2004

1234 Frederick van der Ploeg, The Welfare State, Redistribution and the Economy, Reciprocal Altruism, Consumer Rivalry and Second Best, July 2004

1235 Thomas Fuchs and Ludger Woessmann, What Accounts for International Differences in Student Performance? A Re-Examination Using PISA Data, July 2004

1236 Pascalis Raimondos-Møller and Alan D. Woodland, Measuring Tax Efficiency: A Tax Optimality Index, July 2004

1237 M. Hashem Pesaran, Davide Pettenuzzo, and Allan Timmermann, Forecasting Time Series Subject to Multiple Structural Breaks, July 2004

1238 Panu Poutvaara and Andreas Wagener, The Invisible Hand Plays Dice: Eventualities in Religious Markets, July 2004

1239 Eckhard Janeba, Moral Federalism, July 2004

1240 Robert S. Chirinko, Steven M. Fazzari, and Andrew P. Meyer, That Elusive Elasticity: A Long-Panel Approach to Estimating the Capital-Labor Substitution Elasticity, July 2004

1241 Hans Jarle Kind, Karen Helene Midelfart, Guttorm Schjelderup, Corporate Tax Systems, Multinational Enterprises, and Economic Integration, July 2004

1242 Vankatesh Bala and Ngo Van Long, International Trade and Cultural Diversity: A Model of Preference Selection, July 2004

1243 Wolfgang Eggert and Alfons J. Weichenrieder, On the Economics of Bottle Deposits, July 2004

1244 Sören Blomquist and Vidar Christiansen, Taxation and Heterogeneous Preferences, July 2004

1245 Rafael Lalive and Alois Stutzer, Approval of Equal Rights and Gender Differences in Well-Being, July 2004

1246 Paolo M. Panteghini, Wide vs. Narrow Tax Bases under Optimal Investment Timing, July 2004 